\title{
Dose Response of Milk Fat to Intravenous Administration of the trans-10, cis-12 Isomer of Conjugated Linoleic Acid ${ }^{1}$
}

\author{
S. Viswanadha, J. G. Giesy, T. W. Hanson, and M. A. McGuire \\ Department of Animal and Veterinary Science, \\ University of Idaho, Moscow 83844
}

\begin{abstract}
Intravenous infusion of conjugated linoleic acid (CLA) was evaluated as a simpler method than abomasal infusion and the feeding of calcium salts to examine milk fat depression. The objectives were to determine the dose-dependent response of milk fat and plasma metabolites to intravenous administration of the trans-10, cis-12 isomer of CLA, an isomer identified to possess an inhibitory effect on milk fat synthesis. Four multiparous Holstein cows averaging $123 \pm 30 \mathrm{~d}$ in milk were randomly assigned to treatments in a $4 \times 4$ Latin square design. Catheters were inserted into the jugular vein for infusions and blood sampling. Treatments consisted of intravenous infusions of $0,2,4$, and 6 g/d CLA ( $>95 \%$ trans-10, cis-12 CLA). Infusates contained $72 \mathrm{~g} / \mathrm{d}$ of a parenteral solution, saline, and CLA to $90 \mathrm{ml}$. Periods were of $5 \mathrm{~d}$ duration with a 7 $\mathrm{d}$ wash out. Milk was sampled at each milking and analyzed for fat, protein, and fatty acids. Blood samples were obtained on the last day of each period. Dry matter intake $(22.4 \pm 2.4 \mathrm{~kg} / \mathrm{d})$, milk yield $(28.5 \pm 3.3$ $\mathrm{kg} / \mathrm{d})$, and protein percent $(3.26 \pm 0.08 \%)$ of cows were not affected by treatment. However, milk fat percentage was reduced linearly with increasing doses of CLA. Milk fat percentage was $4.17,3.53,3.29$, and $2.92 \%$ on d 5 for treatments $0,2,4$, and $6 \mathrm{~g} / \mathrm{d}$ CLA, respectively. Concentrations ( $4.2 \mathrm{mg} / \mathrm{g}$ of fat) of cis-9, trans-11 CLA in milk fat were not affected by treatment. However, an increase in the trans-10, cis-12 CLA content of milk fat was observed. Milk fat contained 0.00, 0.02, 0.06, and $0.10 \mathrm{mg}$ of trans-10, cis-12 CLA per $\mathrm{g}$ of fat (SEM $=0.065$ ) for treatments $0,2,4$, and $6 \mathrm{~g} / \mathrm{d}$ CLA, respectively. Plasma NEFA concentration increased linearly with the dose of the trans-10, cis-12 CLA. Intravenous infusion of the trans-10, cis-12 isomer of CLA depressed milk fat in a linear manner over the range of
\end{abstract}

Received November 20, 2002.

Accepted May 15, 2003.

Corresponding author: M. A. McGuire; e-mail: mmcguire@ uidaho.edu.

${ }^{1}$ Idaho Agricultural Experimental Station publication \#03A01. infusion studied and, therefore, is an alternative to abomasal infusion.

(Key words: conjugated linoleic acid, milk fat, dairy cattle)

Abbreviation key: CLA = conjugated linoleic acid.

\section{INTRODUCTION}

Conjugated linoleic acid (CLA) refers to a mixture of positional and geometrical isomers of octadecadienoic acids with conjugated double bonds. Conjugated linoleic acid has been demonstrated to possess a wide range of health benefits, which include suppression of carcinogenesis (Pariza and Hargraves, 1985; Ha et al., 1987; Ip et al., 1994), reduction in atherogenesis (Nicolosi et al., 1997), improvement in glycemic status in diabetic rats (Houseknecht et al., 1998), and modulation of the immune system (Cook et al., 1993). Conjugated linoleic acid has been identified in various food sources. Milk and other dairy products are considered to be good sources of CLA, while vegetable oils and seafood contain minimal amounts of these fatty acids (Chin et al., 1992). Conjugated linoleic acid is formed in the rumen as an intermediate in the biohydrogenation pathway (Shortland et al., 1955). It can also be formed in tissues from trans vaccenic acid by the action of the enzyme $\Delta^{9}$-desaturase (Griinari et al., 2000). trans-Vaccenic acid is an intermediate in the biohydrogenation of several polyunsaturated fatty acids.

Apart from the potential health benefits mentioned, CLA has profound effects on lipid metabolism. Research has demonstrated that mixtures of CLA isomers either infused abomasally (Chouinard et al., 1999a) or when fed as calcium salts (Giesy et al., 2002) cause a dose dependent reduction in milk fat. Baumgard et al. (2000) demonstrated that the trans-10, cis12 isomer of CLA but not the cis-9, trans-11 isomer of CLA was responsible for milk fat depression. Abomasal infusion requires surgically prepared animals, and feeding of calcium salts of CLA requires manufacturing and does not necessarily deliver the expected dose of CLA due to incomplete protection from rumen biohydrogenation. The objective of the study was to examine 
Table 1. Fatty acid profile of trans-10, cis-12 conjugated linoleic acid ${ }^{1}$ (CLA) infused intravenously into lactating dairy cows.

\begin{tabular}{lc}
\hline Fatty acid & Percent \\
\hline $\mathrm{C}_{16: 0}$ & 1.1 \\
$\mathrm{C}_{18: 0}$ & 0.3 \\
$\mathrm{C}_{18: 1}$ cis-9 & 0.3 \\
$\mathrm{C}_{18: 2}$ cis-9, trans-11 (CLA) & 1.6 \\
$\mathrm{C}_{18: 2}$ trans-10, cis-12 (CLA) & 94.8 \\
Unknown & 1.9 \\
\hline
\end{tabular}

${ }^{1}$ Natural Lipids, Hovdebygda, Norway,

whether intravenous infusion could be utilized to simplify the experimental examination of the metabolic effects of CLA on milk fat synthesis. The study evaluated the dose-dependent response of milk parameters and plasma metabolites to intravenous administration of the trans-10, cis-12 isomer of CLA. Intravenous administration of the trans-10, cis-12 CLA was hypothesized to depress milk fat linearly with dose, and the extent of its incorporation into milk fat would vary positively with the dose of the trans-10, cis-12 CLA infused.

\section{MATERIALS AND METHODS}

All procedures involving animals were approved by the Animal Care and Use Committee of the University of Idaho. Four multiparous Holstein cows averaging $123 \pm 30$ DIM were used for the purpose of this study. Cows were randomly assigned to a treatment sequence in a $4 \times 4$ Latin square design. Treatments consisted of intravenous infusions of $0,2,4$, and $6 \mathrm{~g} / \mathrm{d}$ of trans10, cis-12 CLA (Natural Lipids, Hovdebyda, Norway; Table 1) suspended in $72 \mathrm{~g}$ of $10 \%$ Intralipid (Baxter; Deerfield, IL) and brought to $90 \mathrm{ml}$ with $0.9 \%$ saline. Sonication for $45 \mathrm{~s}$ ensured thorough mixing. The daily infusate was divided into six equal doses, loaded into syringes, and infused every $4 \mathrm{~h}$. The dose range was based upon the amount of trans-10, cis-12 CLA infused abomasally by Chouinard et al. (1999a, 1999b). Periods were of 5-d duration with a 7-d interval to minimize any carryover effects of CLA. Cows were housed in free stalls but fed individually through the Calan (American Calan Inc., Northwood, NH) system. Cows were fed a diet formulated to meet their nutrient requirements (NRC, 1989; Table 2). Cows were fed to ad libitum intake with equal portions of feed offered at 0730 and $1730 \mathrm{~h}$ daily. In addition, water was available at all times. Daily feed refusals were weighed and removed before feeding at $0730 \mathrm{~h}$. Cows were milked at 0500 and $1700 \mathrm{~h}$ daily. Milk yield was determined at each milking and samples were obtained. One aliquot was analyzed for fat, protein, and lactose content
Table 2. Ingredient and chemical composition of the diet.

\begin{tabular}{lc}
\hline Composition & Content \\
\hline Ingredient, \% DM & \\
Chopped alfalfa hay & 27.6 \\
Pea and triticale silage & 7.7 \\
Whole cottonseed & 10.7 \\
Steam-rolled corn & 15.0 \\
Energy Booster & 1.4 \\
Barley & 21.8 \\
Dried distillers' grains & 5.4 \\
Soybean meal & 4.9 \\
Blood meal & 0.8 \\
Fish meal & 0.8 \\
Trace mineral premix & 0.7 \\
Vitamin premix & \\
Limestone & 0.3 \\
Dicalcium phosphate & 1.4 \\
Magnesium oxide & 0.5 \\
Sodium bicarbonate & 0.2 \\
Chemical analysis & 0.9 \\
CP, \% DM & \\
Crude fat, \% DM & 20.4 \\
NDF, \% DM & 6.3 \\
ADF, \% DM & 30.3 \\
Ash, $\%$ DM & 17.8 \\
NE, Mcal/kg & 8.6 \\
\hline
\end{tabular}

${ }^{1}$ Milk Specialties, Dundee, IL.

${ }^{2}$ Trace mineral mix (mg/kg mix) contained: Mn, 3500; Zn, 3000; $\mathrm{Cu} 750 ; \mathrm{Fe}, 20$; I, 85; Co, 15; and Se, 35.

${ }^{3}$ Vitamin premix provided $2,110,000 \mathrm{IU} / \mathrm{kg}$ of retinyl acetate, $390,000 \mathrm{IU} / \mathrm{kg}$ cholecalciferol, and $7,550 \mathrm{IU} / \mathrm{kg}$ dl- $\alpha$-tocopheryl acetate.

by infrared analysis (Washington DHI, Burlington, WA).

Lipid extraction of milk was performed using the Folch procedure (1957) with modifications (Clark et al., 1982). Milk fatty acids were transesterified with sodium methoxide according to the method of Christie (1982). Analysis of methyl esters was performed on a GLC (Hewlett Packard 6890 Series with auto injector) fitted with a flame-ionization detector. Fatty acid profile was determined by split injection (20:1) onto a CPSil 88 fused silica capillary column $(100 \mathrm{~m} \times 0.25 \mathrm{~mm}$, Chrompack, Raritan, NJ) using a programmed temperature gradient method. The hydrogen carrier gas pressure was constant, and the injector and detector temperatures were $255^{\circ} \mathrm{C}$. Initial oven temperature was $70^{\circ} \mathrm{C}$. Following injection of sample, oven temperature was increased at $1^{\circ} \mathrm{C} / \mathrm{min}$ to $185^{\circ} \mathrm{C}$ and held for $20 \mathrm{~min}$. Oven temperature was then increased at $3^{\circ} \mathrm{C} /$ min to $215^{\circ} \mathrm{C}$ followed by an increase at $10^{\circ} \mathrm{C} / \mathrm{min}$ to $240^{\circ} \mathrm{C}$ and held for 5 min after which oven temperature was returned to $70^{\circ} \mathrm{C}$. Individual fatty acids were identified by comparison of retention times to those of pure standards (Matreya Inc., Pleasant Gap, PA). A response correction factor for each fatty acid methyl ester was used to convert peak area percentage to weight percentage. Correction factors were determined by an- 
alyzing butter oil of a known fatty acid profile with certified values (CRM 164; European Community Bureau of Reference, Brussels, Belgium).

Catheters were inserted into the jugular vein for infusions and blood sampling using polyvinyl tubing. An intramuscular injection $(1 \mathrm{~g} / \mathrm{d}$ ) of Naxcel (Pharmacia \& Upjohn, Kalamazoo, MI) was administered to the animals immediately after catheterization as a prophylactic measure. Catheters were installed from $2 \mathrm{~d}$ before through the end of each period.

Blood samples were obtained once each period at $1400 \mathrm{~h}$ on d 5 of CLA infusion. Plasma was harvested after centrifugation at $2300 \times \mathrm{g}$ for $15 \mathrm{~min}$ and stored at $-20^{\circ} \mathrm{C}$ until analyzed. Plasma glucose concentration was determined by enzymatic colorimetric analysis using a commercial kit (510-DA; Sigma, St. Louis, MO). Triacylglycerol and glycerol concentrations were estimated using a commercial kit (336-10; Sigma) according to the manufacturer's instructions. Nonesterified fatty acids were determined by enzyme colorimetric analysis (Wako Pure Chemical Industries, Osaka, Japan) with modifications (Sechen et al., 1990).

\section{Statistical Analysis}

Data were statistically analyzed as a $4 \times 4$ Latin square design using the general linear model procedure of SAS version 8.0 (1999) according to the following model:

$$
\mathrm{Y}_{\mathrm{ijkl}}=\mu+\mathrm{T}_{\mathrm{i}}+\mathrm{P}_{\mathrm{j}}+\mathrm{C}_{\mathrm{k}}+\mathrm{E}_{\mathrm{ijkl}} \text {, }
$$

where $\mathrm{Y}_{\mathrm{ijkl}}$ is the observation, $\mu$ is the overall mean, $\mathrm{T}_{\mathrm{i}}$ is the treatment ( $\mathrm{i}=0,2,4$, and $6 \mathrm{~g} / \mathrm{d}$ of CLA), $\mathrm{P}_{\mathrm{j}}$ is the period $(\mathrm{j}=1,2,3$, and 4$), \mathrm{C}_{\mathrm{k}}$ is the cow $(\mathrm{k}=1$, 2,3 , and 4 ), and $\mathrm{E}_{\mathrm{ijkl}}$ is the residual error. Preplanned comparisons were used to test the linear, quadratic or cubic effect of dose of CLA when effect of treatment was significant. Differences were declared at $P<0.05$.

\section{RESULTS}

Infusion of the trans-10, cis-12 CLA had no effect on DMI, which averaged $22.4 \mathrm{~kg} / \mathrm{d}$ (Table 3 ). Milk yield and milk protein were similar for all the treatment groups. In contrast, intravenous infusion of the trans10 , cis-12 CLA resulted in a dramatic reduction in milk fat percent over the 5 -d infusion period. Milk fat percentage decreased gradually over the 5-d period (Figure 1). Milk fat percent and yield averaged $2.92 \%$ and $842 \mathrm{~g} / \mathrm{d}$ for the $6 \mathrm{~g} / \mathrm{d}$ dose of the trans-10, cis-12 CLA compared with $4.17 \%$ and $1055 \mathrm{~g} / \mathrm{d}$ for the control group $(P<0.05$; Table 3$)$. Infusion of the trans-10, cis12 CLA caused linear decreases $(P<0.05)$ in the milk fat concentration of $\mathrm{C}_{6: 0}$, whereas the other short- and medium-chain fatty acids $\left(\mathrm{C}_{4: 0}, \mathrm{C}_{8: 0}, \mathrm{C}_{10: 0}, \mathrm{C}_{12: 0}\right.$, and $\mathrm{C}_{14: 0}$ ) remained unchanged (Table 4). Most of the longchain fatty acids were not affected except for linear increases $(P<0.05)$ in the concentration of $\mathrm{C}_{18: 2}$ and $\mathrm{C}_{19: 0}($ Table 4). Combining milk fat yield and fatty acid composition, data demonstrated that infusion of trans10, cis-12 CLA linearly decreased $(P<0.05)$ yields of $\mathrm{C}_{6: 0}, \mathrm{C}_{8: 0}, \mathrm{C}_{10: 0}, \mathrm{C}_{12: 0}$ and $\mathrm{C}_{16: 0}$, whereas yields of $\mathrm{C}_{4: 0}$, $\mathrm{C}_{16: 1}, \mathrm{C}_{17: 0}, \mathrm{C}_{18: 0}, \mathrm{C}_{18: 1}, \mathrm{C}_{18: 2}$, and $\mathrm{C}_{18: 3}$ remained unchanged (Table 5). Infusion of trans-10, cis-12 CLA linearly increased $(P<0.05)$ the trans-10, cis-12 CLA content of milk fat and yield. Milk fat concentration and yield of trans-10, cis-12 CLA increased from undetectable for the $0 \mathrm{~g} / \mathrm{d}$ dose to $1.0 \mathrm{mg} / \mathrm{g}$ of fat and $0.9 \mathrm{~g} / \mathrm{d}$ for the $6 \mathrm{~g} / \mathrm{d}$ dose of the isomer. Milk fat content and yield of cis-9, trans-11 CLA, however, remained unchanged (Tables 4 and 5).

Plasma metabolites such as NEFA, glucose, triacylglycerol, and glycerol were also examined. Glucose concentrations were not affected by the trans-10, cis-12 CLA infusion and averaged $65 \mathrm{mg} / \mathrm{dl}$ (Table 6). However, a linear increase $(P<0.05)$ in the NEFA and glycerol concentration of plasma to the dose of the trans-10, cis-12 CLA infused was observed (Table 6). Concentration of plasma triacylglycerol was not affected by infusion of the trans-10, cis-12 CLA (Table 6).

\section{DISCUSSION}

Several theories have been proposed to explain the causes of milk fat depression in lactating cows. Dietary factors such as the amount of roughage (Jorgensen et al., 1965; Storry et al., 1974), forage to concentrate ratio (Sutton, 1989), and amount and type of dietary lipids (Sutton, 1989) bring about marked changes in the concentration of milk fat. trans-Fatty acids, derived from the diet or produced by rumen biohydrogenation or animal metabolism, have been suggested to cause milk fat depression (Davis and Brown, 1970; Astrup et al., 1975; Griinari et al., 1998). More recently, abomasal infusions of CLA mixtures have resulted in dramatic reductions in milk fat concentration (Chouinard et al., 1999a, 1999b; Loor and Herbein, 1998). Baumgard et al. (2000) identified the trans-10, cis-12 isomer of CLA as a potent inhibitor of milk fat synthesis and suggested that CLA containing a transdouble bond at carbon-10 appeared to be the key to reducing milk fat synthesis. In this study, the response of milk fat to intravenous administration of various doses of the trans-10, cis-12 isomer of CLA was examined.

Six grams of trans-10, cis-12 CLA infused intravenously resulted in a 30 and $20 \%$ reduction in milk 
Table 3. Least squares means of DMI, milk yield, and composition of milk from lactating dairy cows during intravenous infusion of trans-10, cis-12 conjugated linoleic acid (CLA). ${ }^{1,2}$

\begin{tabular}{lcccccc}
\hline & \multicolumn{9}{c}{ Dose of CLA (g/d) } & & Linear \\
\cline { 2 - 6 } Variable & 0 & 2 & 4 & 6 & SEM & contrast $^{3}$ \\
\hline DMI, kg/d & 21.4 & 24.4 & 21.1 & 22.0 & 2.4 & - \\
Milk yield, kg/d & 25.3 & 34.6 & 28.0 & 28.6 & 3.3 & - \\
Milk protein, \% & 3.32 & 3.32 & 3.26 & 3.20 & 0.1 & - \\
Milk protein yield, g/d & 836 & 1177 & 905 & 918 & 92 & - \\
Milk fat, \% & 4.17 & 3.53 & 3.29 & 2.92 & 0.2 & $* *$ \\
Milk fat yield, g/d & 1055 & 1215 & 893 & 842 & 83 & $*$ \\
\hline
\end{tabular}

${ }^{1}$ Trans-10, cis-12 CLA; Natural Lipids, Hovdebygda, Norway.

${ }^{2}$ Values represent d-5 of infusion.

${ }^{3}$ Contrasts were evaluated only if main effect of dose was significant $(P<0.05)$. Lack of main effect of dose is designated by - No significant quadratic or cubic effects of level of infusion were detected.

$* P<0.05$.

$* * P<0.01$

fat percentage and yield, respectively, over the 5-d infusion period and the depression in milk fat percentage varied linearly with the dose of CLA infused. Similar reductions in milk fat percentage were obtained when a mixture of CLA isomers (Chouinard et al., 1999a) or when the trans-10, cis-12 CLA was infused abomasally (Baumgard et al., 2000). Abomasal infusion of $150 \mathrm{~g} / \mathrm{d}$ of CLA supplement containing $31 \mathrm{~g} / \mathrm{d}$ of trans-10, cis-12 CLA caused a 56 and $63 \%$ reduction in milk fat percent and yield, respectively (Chouinard et al., 1999a), whereas abomasal infusion of $10 \mathrm{~g} / \mathrm{d}$ of trans-10, cis-12 CLA reduced milk fat percentage and yield by 42 and $44 \%$, respectively (Baumgard et al., 2000). When compared on a unit dose basis (decrease

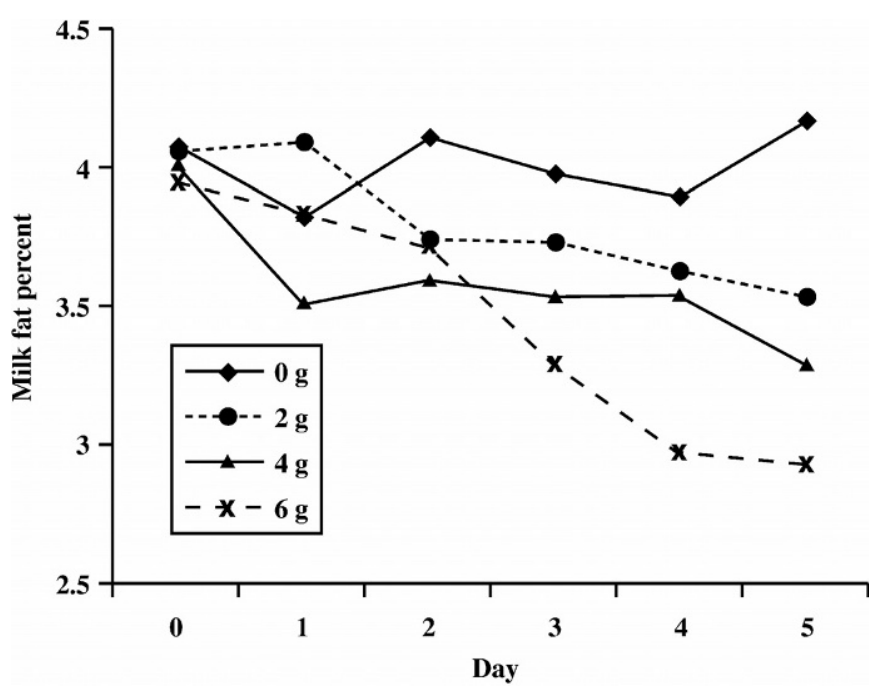

Figure 1. Temporal pattern of milk fat content in dairy cows during intravenous infusion of $0,2,4$, and $6 \mathrm{~g} / \mathrm{d}$ of the trans-10, cis12 conjugated linoleic acid (Natural Lipids, Norway). Values represent least squares means for four cows $(\mathrm{SEM}=0.16)$. in milk fat percentage per gram of trans-10, cis-12 CLA), intravenous administration of the trans-10, cis12 isomer resulted in a greater reduction in milk fat percentage (5\% per gram of trans-10, cis-12 CLA) than abomasal infusions of a CLA mixture (1.8\% per gram of trans-10, cis-12 CLA; Chouinard et al., 1999a) but similar to abomasal infusions of trans-10, cis-12 CLA (4.2\% per gram of trans-10, cis-12 CLA; Baumgard et al., 2000). However, the decrease in fat yield was less compared to previous studies (Chouinard et al., 1999b; Baumgard et al., 2000). This is mainly due to the variation in milk yield noted particularly during the $0 \mathrm{~g} / \mathrm{d}$ trans-10, cis-12 CLA treatment. Baumgard et al. (2001) infused nearly identical trans-10, cis-12 CLA abomasally at doses of 3.5, 7.0, and $14.0 \mathrm{~g} / \mathrm{d}$ and observed depression of milk fat yield similar to that in the current study. Clearly, intravenous infusion of trans-10, cis-12 CLA appears to affect milk fat production similar to abomasal infusion.

Reduction in milk fat output is sometimes associated with body fat accretion in dairy cattle (Davis and Brown, 1970). However, dietary CLA supplements have decreased body fat accretion in growing mice (Park et al., 1997) and pigs (Dugan et al., 1997; Ostrowska et al., 1999). Reduction in milk fat output with no change in body condition would therefore be expected to be associated with a decrease in energy intake of cows (Chouinard et al., 1999a). Abomasal infusions of CLA mixtures (Loor and Herbein, 1998; Chouinard et al., 1999a) or trans-10, cis-12 CLA (Baumgard et al., 2000 ) did not affect voluntary intake in lactating cows. Dry matter intake was not affected in the present study, but long-term studies would be necessary to evaluate the effect of the trans-10, cis-12 CLA on body fat and DMI. Infusion of the trans-10, cis-12 CLA, or CLA mixtures did not affect milk yield and milk protein similar to previous studies (Loor and Herbein, 
Table 4. Least squares means of fatty acid composition of milk fat ( $\mathrm{g} / 100 \mathrm{~g}$ of fatty acids) during intravenous infusion of trans-10, cis-12 conjugated linoleic acid (CLA). ${ }^{1,2}$

\begin{tabular}{|c|c|c|c|c|c|c|}
\hline \multirow[b]{2}{*}{ Fatty acid } & \multicolumn{4}{|c|}{ Dose of CLA (g/d) } & \multirow[b]{2}{*}{ SEM } & \multirow{2}{*}{$\begin{array}{c}\text { Linear } \\
\text { contrast }\end{array}$} \\
\hline & 0 & 2 & 4 & 6 & & \\
\hline $\mathrm{C}_{4: 0}$ & 4.12 & 3.79 & 3.64 & 3.71 & 0.47 & - \\
\hline $\mathrm{C}_{6: 0}$ & 1.97 & 1.95 & 1.81 & 1.67 & 0.09 & $*$ \\
\hline $\mathrm{C}_{8: 0}$ & 1.11 & 1.00 & 0.93 & 0.88 & 0.06 & - \\
\hline $\mathrm{C}_{10: 0}$ & 2.31 & 2.20 & 1.96 & 1.75 & 0.15 & - \\
\hline $\mathrm{C}_{12: 0}$ & 2.44 & 2.41 & 2.23 & 1.90 & 0.18 & - \\
\hline $\mathrm{C}_{14: 0}$ & 7.16 & 7.54 & 7.39 & 8.13 & 0.70 & - \\
\hline $\mathrm{C}_{14: 1} c i s-9$ & 0.58 & 0.57 & 0.60 & 0.61 & 0.02 & - \\
\hline $\mathrm{C}_{15: 0}$ & 0.56 & 0.63 & 0.63 & 0.63 & 0.03 & - \\
\hline $\mathrm{C}_{16: 0}$ & 25.99 & 25.65 & 25.36 & 26.73 & 1.25 & - \\
\hline $\mathrm{C}_{16: 1} c i s-9$ & 1.39 & 1.33 & 1.15 & 1.03 & 0.14 & - \\
\hline $\mathrm{C}_{17: 0}$ & 0.54 & 0.51 & 0.47 & 0.50 & 0.02 & - \\
\hline $\mathrm{C}_{18: 0}$ & 15.80 & 15.99 & 14.34 & 15.13 & 0.58 & - \\
\hline $\mathrm{C}_{18: 1} c i s-9$ & 27.50 & 27.66 & 26.74 & 26.73 & 1.26 & - \\
\hline $\mathrm{C}_{18: 2}$ cis -9, cis -12 & 4.34 & 4.45 & 4.75 & 5.03 & 0.23 & - \\
\hline $\mathrm{C}_{18: 3}$ cis -9, cis -12, cis -15 & 0.39 & 0.40 & 0.38 & 0.37 & 0.02 & - \\
\hline $\mathrm{C}_{18: 2}$ cis-9, trans-11 (CLA) & 0.41 & 0.33 & 0.47 & 0.47 & 0.04 & - \\
\hline $\mathrm{C}_{18: 2}$ trans -10, cis -12 (CLA) & 0.00 & 0.02 & 0.06 & 0.10 & 0.01 & $* * *$ \\
\hline $\mathrm{C}_{19: 0}$ & 0.30 & 0.31 & 0.36 & 0.45 & 0.02 & - \\
\hline $\mathrm{C}_{20: 0}$ & 0.11 & 0.13 & 0.14 & 0.14 & 0.02 & - \\
\hline
\end{tabular}

${ }^{1}$ Trans-10, cis-12 CLA; Natural Lipids, Hovdebygda, Norway.

${ }^{2}$ Values represent d 5 of infusion.

${ }^{3}$ Contrasts were evaluated only if main effect of dose was significant $(P<0.05)$. Lack of main effect of dose is designated by - . No significant quadratic or cubic effects of level of infusion were detected.

$* P<0.05$.

$* * * P<0.001$.

1998; Chouinard et al., 1999a; Baumgard et al., 2000). The length of the infusion was likely too short to affect milk yield. Giesy (2000) demonstrated that long-term feeding of calcium salts of a mixture of CLA might increase milk yield without any effect on DMI in early lactation, whereas Perfield et al. (2002) did not detect any effect of calcium salts of CLA on milk yield or DMI from cows in late lactation.

The fatty acid profile of milk fat revealed a marked reduction in the yield of short-chain fatty acids that arise from de novo synthesis in the mammary gland during CLA infusion (Table 5). Thus, the trans-10, cis-12 isomer evidently inhibited de novo fatty acid synthesis. A possible mechanism could be via the suppression of acetyl-CoA carboxylase (Bauman et al., 2000). Acetyl-CoA carboxylase catalyzes the initial reaction in de novo synthesis of fatty acids in animal tissues and is considered the rate-limiting step. In the current study, infusion of the trans-10, cis-12 CLA had no effect on the yield of $\mathrm{C}_{14: 0}$ and $\mathrm{C}_{14: 1}$ unlike the observations by Chouinard et al. (1999b). Reasons for these inconsistencies may be related to the dose of the trans-10, cis-12 CLA infused ( 6 vs. $8.3 \mathrm{~g} / \mathrm{d}$ ), extent of milk fat depression ( $20 \mathrm{vs} .28 \%$ ), the mode of administration (intravenous vs. abomasal), dietary lipid concentration, and dietary fatty acid profile. Yield of $\mathrm{C}_{16: 0}$ decreased with infusion of the trans-10, cis-12 CLA.
Long-chain fatty acids secreted as milk fat are derived from the diet or body stores. A decrease in the output of long-chain fatty acids in milk could indicate a reduction in the mobilization from adipose tissue. However, an increase in concentration of NEFA in plasma was detected, suggesting that mobilization was increased, not decreased. Possibly a decrease in mammary uptake of the long-chain fatty acids caused an increase in the pool of NEFA in circulation as well as a decrease in their output in milk. Most of the long-chain fatty acids such as $\mathrm{C}_{18: 1}, \mathrm{C}_{18: 2}, \mathrm{C}_{18: 3}$, and $\mathrm{C}_{19: 0}$ were unaffected. Milk fat content and yield of trans-10, cis-12 CLA increased $(P<0.05)$ linearly with the dose of the isomer infused, and the efficiency of incorporation into milk fat was calculated to be approximately $14 \%$ when compared to $10 \%$ observed by Chouinard et al. (1999a). No effect on cis-9, trans-11 CLA was observed. Griinari et al. (2000) suggested that the majority of cis-9, trans11 CLA found in milk was produced by action of the $\Delta^{9}$-desaturase enzyme within mammary tissue. It appears that the formation of cis-9, trans-11 CLA from trans-11 vaccenic acid is unaffected by infusion of trans-10, cis-12 CLA. Thus, at the dosages infused, the trans-10, cis-12 CLA did not affect the activity of the $\Delta^{9}$-desaturase enzyme related formation of cis9, trans-11 CLA from trans-11 vaccenic acid. 
Table 5. Least squares means of fatty acids yields (g/d) during intravenous infusion of trans-10, cis-12 conjugated linoleic acid (CLA). ${ }^{1,2}$

\begin{tabular}{|c|c|c|c|c|c|c|}
\hline \multirow[b]{2}{*}{ Fatty acid } & \multicolumn{4}{|c|}{ Dose of CLA (g/d) } & \multirow[b]{2}{*}{ SEM } & \multirow{2}{*}{$\begin{array}{c}\text { Linear } \\
\text { contrast }^{3}\end{array}$} \\
\hline & 0 & 2 & 4 & 6 & & \\
\hline $\mathrm{C}_{4: 0}$ & 45.7 & 46.5 & 32.7 & 33.1 & 7.7 & - \\
\hline$C_{6: 0}$ & 21.2 & 24.0 & 16.2 & 14.5 & 2.2 & $*$ \\
\hline $\mathrm{C}_{8: 0}$ & 11.7 & 12.3 & 8.4 & 7.7 & 1.1 & $*$ \\
\hline $\mathrm{C}_{10: 0}$ & 24.3 & 26.6 & 17.4 & 14.6 & 2.0 & $* *$ \\
\hline $\mathrm{C}_{12: 0}$ & 25.6 & 29.6 & 19.7 & 16.3 & 2.2 & $* *$ \\
\hline $\mathrm{C}_{14: 0}$ & 76.5 & 95.5 & 64.7 & 68.6 & 7.7 & - \\
\hline $\mathrm{C}_{14: 1} c i s-9$ & 6.4 & 7.6 & 5.3 & 6.4 & 0.7 & - \\
\hline $\mathrm{C}_{15: 0}$ & 5.9 & 7.7 & 5.7 & 5.3 & 0.5 & - \\
\hline $\mathrm{C}_{16: 0}$ & 275.0 & 316.5 & 222.1 & 224.1 & 19.1 & $*$ \\
\hline $\mathrm{C}_{16: 1}$ cis-9 & 15.2 & 16.3 & 10.8 & 8.6 & 2.3 & - \\
\hline $\mathrm{C}_{17: 0}$ & 5.7 & 6.1 & 4.1 & 4.2 & 0.5 & - \\
\hline $\mathrm{C}_{18: 0}$ & 163.0 & 192.3 & 127.6 & 129.9 & 14.1 & - \\
\hline $\mathrm{C}_{18: 1}$ cis -9 & 290.4 & 333.0 & 235.8 & 224.7 & 33.2 & - \\
\hline $\mathrm{C}_{18: 2}$ cis -9, cis- 12 & 45.5 & 51.4 & 42.9 & 43.0 & 6.2 & - \\
\hline $\mathrm{C}_{18: 3}$ cis -9, cis -12, cis -15 & 4.2 & 4.7 & 3.3 & 3.1 & 0.4 & - \\
\hline $\mathrm{C}_{18: 2}$ cis-9, trans-11 (CLA) & 4.5 & 4.1 & 4.2 & 3.8 & 0.9 & - \\
\hline $\mathrm{C}_{18: 2}$ trans -10, cis-12 (CLA) & 0.0 & 0.3 & 0.5 & 0.9 & 0.1 & $* *$ \\
\hline $\mathrm{C}_{19: 0}$ & 3.2 & 3.9 & 3.2 & 3.9 & 0.3 & - \\
\hline $\mathrm{C}_{20: 0}$ & 1.1 & 1.7 & 1.3 & 1.2 & 0.1 & - \\
\hline
\end{tabular}

${ }^{1}$ Trans-10, cis-12 CLA; Natural Lipids, Hovdebygda, Norway.

${ }^{2}$ Values represent d 5 of infusion.

${ }^{3}$ Contrasts were evaluated only if main effect of dose was significant $(P<0.05)$. Lack of main effect of dose is designated by - . A cubic effect $(P<0.05)$ of dose of CLA was detected for $\mathrm{C}_{16: 0}$.

$* P<0.05$.

$* * P<0.01$

Intravenous infusion of trans-10, cis-12 CLA brought about a drastic increase in the plasma NEFA concentration, and this increase was linear to the dose of the isomer infused. Baumgard et al. (2000) demonstrated a small increase (17\%) in the plasma NEFA concentration upon abomasal infusion of the trans10, cis-12 CLA; however, the increase observed upon intravenous infusion was much higher (217\%). In lactating dairy cattle, elevation of plasma NEFA concentration is usually caused by a rapid decline in the net energy balance, either caused by a reduction in DMI or an increase in milk yield without an increase in DMI. This is usually followed by an increase in the long-chain fatty acid content of milk fat that are characteristic of body fat reserves (Bauman et al., 1988). No increase in the long-chain fatty acid content of milk fat was detected, although there was a marked increase in the plasma NEFA concentration upon administration of the trans-10, cis-12 CLA. A plausible explanation for this observed increase in NEFA could be that fatty acids, during breakdown of triacylglycerides by lipoprotein lipase, were not completely taken up by extrahepatic tissues but were released into circulation (Grummer and Carrol, 1991). Gagliostro et al. (1991) suggested that some NEFA might be released during triacylglyceride hydrolysis by tissue lipopro-

Table 6. Least squares means of plasma concentrations of glucose, triacylglycerol, glycerol, and NEFA during intravenous infusions of trans-10, cis-12 conjugated linoleic acid (CLA). ${ }^{1,2}$

\begin{tabular}{|c|c|c|c|c|c|c|}
\hline \multirow[b]{2}{*}{ Variable } & \multicolumn{4}{|c|}{ Dose of CLA (g/d) } & \multirow[b]{2}{*}{ SEM } & \multirow{2}{*}{$\begin{array}{c}\text { Linear } \\
\text { contrast }^{3}\end{array}$} \\
\hline & 0 & 2 & 4 & 6 & & \\
\hline Glucose, mg/dl & 63.9 & 66.1 & 64.3 & 66.2 & 3.2 & - \\
\hline Triacylglycerol, $\mu M$ & 222 & 267 & 243 & 276 & 30 & - \\
\hline Glycerol, $\mu M$ & 894 & 1043 & 1098 & 1478 & 91 & ** \\
\hline NEFA, $\mu M$ & 365 & 486 & 652 & 1159 & 122 & $* *$ \\
\hline
\end{tabular}

${ }^{1}$ Trans-10, cis-12 CLA; Natural Lipids, Hovdebygda, Norway.

${ }^{2}$ Values represent d 5 of infusion.

${ }^{3}$ Contrasts were evaluated only if main effect of dose was significant $(P<0.05)$. Lack of main effect of dose is designated by - . No significant quadratic or cubic effects of dose of CLA were detected.

$* * P<0.01$ 
tein lipase. Infusions also resulted in a dose-dependent increase in the plasma glycerol concentration. Park et al. (1999) showed that trans-10, cis-12 isomer reduced lipoprotein lipase activity in cultured 3T3-L1 adipocytes and enhanced glycerol release into the medium. Increased plasma NEFA and glycerol might therefore result because of increased net fatty acid and glycerol release from adipose, a decrease in NEFA clearance by tissues or a combination of both. This might indicate a decrease in lipogenesis, probably due to inhibition of the enzyme lipoprotein lipase as shown by Park et al. (1999) with normal lipolytic activity in adipose tissue. Decreased lipogenesis with normal lipolytic activity in adipose tissue would affect fatty acid turnover, thus increasing the concentration of NEFA and glycerol in the blood stream.

\section{CONCLUSION}

Intravenous infusion of the trans-10, cis-12 CLA was evaluated as a simpler method compared with abomasal infusion and the feeding of calcium salts to examine milk fat depression. A dose-dependent decrease in milk fat percentage and yield was detected with intravenous infusion of trans-10, cis-12 CLA. The response of milk fat percentage to intravenous administration of trans-10, cis-12 CLA was similar to other studies using abomasal infusion of CLA or the feeding of calcium salts of CLA. Furthermore, the trans-10, cis-12 CLA isomer was incorporated into milk fat in a dosedependent manner without affecting the content of $\mathrm{cis}$ 9, trans-11 CLA over the dose range studied. Intravenous administration of trans-10, cis-12 CLA can be used to perform studies evaluating the mechanism of milk fat depression.

\section{ACKNOWLEDGMENTS}

The authors express their gratitude to Roger Falen for his assistance during laboratory procedures. The United Dairymen of Idaho and the Idaho Agricultural Experiment Station supported the work.

\section{REFERENCES}

Astrup, H. N., L. Vikmo, A. Ekern, and F. Bakke. 1975. Feeding protected and unprotected oils to dairy cows. J. Dairy Sci. $59: 426-430$.

Bauman, D. E., C. J. Peel, W. D. Steinhour, P. J. Reynolds, H. F. Tyrell, A. C. G. Brown, and G. L. Haaland. 1988. Effect of bovine somatotropin on metabolism of lactating dairy cows: Influence on rates of irreversible loss and oxidation of glucose and non esterified fatty acids. J. Nutr. 118:1031-1040.

Bauman, D. E., L. H. Baumgard, B. A. Corl, and J. M. Griinari. 2000. Biosynthesis of conjugated linoleic acid in ruminants. Proc. Am. Soc. Anim. Sci, 1999. Available: http://www.asas.org/jas/ symposia/proceedings/0937.pdf. Accessed June 5, 2000.
Baumgard, L., B. Corl, D. Dwyer, A. Saebo, and D. E. Bauman. 2000. Identification of the CLA isomer which inhibits milk fat synthesis. Am. J. Physiol. 278:R179-R184.

Baumgard, L. H., J. K. Sangster, and D. E. Bauman. 2001. Milk fat synthesis in dairy cows is progressively reduced by increasing supplemental amounts of trans-10, cis-12 conjugated linoleic acid (CLA). J. Nutr. 131:1764-1769.

Chin, S. F., W. Liu, J. M. Storkson, Y. L. Ha, and M. W. Pariza. 1992. Dietary sources of conjugated dienoic isomers of linoleic acid, a newly recognized class of anticarcinogens. J. Food Comp. Anal. 5:185-197.

Chouinard, P. Y., L. Corneau, D. M. Barbano, L. E. Metzger, and D. E. Bauman. 1999a. Conjugated linoleic acids alter milk fatty acid composition and inhibit milk fat secretion in dairy cows. J. Nutr. 129:1579-1584.

Chouinard, P. Y., L. Corneau, A. Saebo, and D. E. Bauman. 1999b. Milk yield and composition during abomasal infusion of conjugated linoleic acids in dairy cows. J. Dairy Sci. 82:2737-2745.

Christie, W. W. 1982. A simple procedure for rapid transmethylation of glycerolipids and cholesteryl esters. J. Lipid Res. 23:10721075.

Clark, R. M., A. M. Ferris, M. Fey, P. B. Brown, K. E. Hundrieser, and R. G. Jensen. 1982. Changes in the lipids of human milk from 2-16 weeks postpartum. J. Pediatr. Gastroenterol. Nutr. 11:311-315.

Cook, M. E., C. C. Miller, Y. Park, and M. W. Pariza. 1993. Immune modulation by altered nutrient metabolism: Nutritional control of immune-induced growth depression. Poult. Sci. 72:1301-1305.

Davis, C. L., and R. E. Brown. 1970. Low milk fat syndrome. Pages 545-565 in Digestion and Metabolism in the Ruminant. A. T. Phillipson, ed. Oriel Press, Newcastle upon Tyne, UK.

Dugan, M. E. R., J. L. Aalhus, A. L. Schaefer, and J. K. G. Kramer. 1997. The effect of conjugated linoleic acid on fat to lean partitioning and feed conversion in pigs. Can. J. Anim. Sci. 77:723-725.

Folch, J., M. Lees, and G. A. Sloane Stanley. 1957. A simple method for the isolation and purification of total lipids from animal tissues. J. Biol. Chem. 226:497-509.

Gagliostro, G., Y. Chilliard, and M. J. Davicco. 1991. Duodenal rapeseed oil infusion in early and midlactation cows. 3. Plasma hormones and mammary apparent uptake of metabolites. J. Dairy Sci. 74:1893-1903.

Giesy, J. G. 2000. Effect of insulin or conjugated linoleic acid (CLA) on composition of milk in lactating dairy cattle. Ph.D. Diss., Univ. Idaho, Moscow.

Giesy, J. G., M. A. McGuire, B. Shafii, and T. W. Hanson. 2002. Effect of dose of calcium salts of conjugated linoleic acid (CLA) on percentage and fatty acid content of milk fat in midlactation Holstein cows. J. Dairy Sci. 85:2023-2029.

Griinari, J. M., B. A. Corl, S. H. Lacy, P. Y. Chouinard, K. V. V. Nurmela, and D. E. Bauman. 2000. Conjugated linoleic acid is synthesized endogenously in lactating dairy cows by $\Delta 9$ - desaturase. J. Nutr. 130:2285-2291.

Griinari, J. M., D. A. Dwyer, M. A. McGuire, D. E. Bauman, D. L. Palmquist, and K. V. V. Nurmela. 1998. trans-octadecenoic acids and milk fat depression in lactating dairy cows. J. Dairy Sci. 81:1251-1261.

Grummer, R. R., and D. J. Carrol. 1991. Effects of dietary fats on metabolic disorders and reproductive performance of dairy cows. J. Anim. Sci. 69:3838-3852.

Ha, Y. L., N. K. Grimm, and M. W. Pariza. 1987. Anticarcinogenesis from fried ground beef: Heat altered derivatives of linoleic acid. Carcinogenesis 8:1881-1887.

Houseknecht, K. L., J. P. Vanden Heuvel, S. Y. Moya-Camarena, C. P. Portocarrero, L. W. Peck, K. P. Nickle, and M. A. Belury. 1998. Dietary conjugated linoleic acid normalizes impaired glucose tolerance in the Zucker diabetic fatty fa/fa rat. Biochem. Biophys. Res. Commun. 244:678-682.

Ip, C., M. Singh, J. H. Thompson, and J. A. Scimeca. 1994. Conjugated linoleic acid suppresses mammary carcinogenesis and proliferative activity of the mammary gland in the rat. Cancer Res. 54:1212-1215. 
Jorgensen, N. A., L. H. Shultz, and G. R. Barr. 1965. Factors influencing milk fat depression in rations high in concentrate. J. Dairy Sci. 48:1031-1039.

Loor, J. J., and J. H. Herbein. 1998. Exogenous CLA isomers reduce bovine milk fat concentration and yield by inhibiting de novo fatty acid synthesis. J. Nutr. 128:2411-2419.

National Research Council. 1989. Nutrient Requirements of Dairy Cattle. 6th rev. ed. National Academy Press, Washington, DC.

Nicolosi, R. J., E. J. Rogers, D. Kritchevsky, J. A. Scimeca, and P. J. Huth. 1997. Dietary conjugated linoleic acid reduces plasma lipoprotein and early aortic atherosclerosis in hypercholesterolemic hamsters. Artery 22:266-277.

Ostrowska, E., M. Muralitharan., R. F. Cross., D. E. Bauman, and F. R. Dunshea. 1999. Dietary conjugated linoleic acids increase lean tissue and decrease fat deposition in growing pigs. J. Nutr. 129:2037-2042.

Pariza, M. W., and W. A. Hargraves. 1985. A beef derived mutagenesis modulation inhibits initiation of mouse epidermal tumors by 7, 12-dimethylbenz(a)anthracene. Carcinogenesis 6:591-593.

Park, Y., K. J. Albright, W. Liu, J. M. Storkson, M. E. Cook, and M. W. Pariza. 1997. Effects of conjugated linoleic acid on body composition in mice. Lipids 32:853-858.
Park, Y., J. M. Storkson., K. J. Albright., W. Liu, and M. W. Pariza. 1999. Evidence that the trans-10, cis-12 isomer of conjugated linoleic acid induces body composition changes in mice. Lipids 34:235-241.

Perfield, J. W., G. Bernal-Santos, T. R. Overton, and D. E. Bauman. 2002. Effects of dietary supplementation of rumen-protected conjugated linoleic acid in dairy cows during established lactation. J. Dairy Sci. 85:2609-2617.

SAS Institute Inc. 1999. SAS/STATS User's Guide, Version 8.0. SAS Institute, Cary, NC.

Sechen, S. J., F. R. Dunshea, and D. E. Bauman. 1990. Somatotropin in lactating cows: effect on response to epinephrine and insulin. Am. J. Physiol. 258:E582-E588.

Shortland, F. B., R. O. Weenink, and A. T. Johns. 1955. Effect of the rumen on dietary fat. Nature 175:1129-1130.

Storry, J. E., P. E. Brumby, A. J. Hall, and V. W. Johnson. 1974. Response in rumen fermentation and milk fat secretion in cows receiving low roughage diets supplemented with protected tallow. J. Dairy Res. 41:165-173.

Sutton, J. D. 1989. Altering milk composition by feeding. J. Dairy Sci. 72:2801-2814. 